\title{
Eindhoven University of Technology Netherlands
}

Department of Electrical Enguneerıng

\section{Development of Transmission Facilities for Electronic Media in the Netherlands}

by

J.C. Arnbak 
Eindhoven University of Technology Research Reports

EINDHOVEN UNIVERSITY OF TECHNOLOGY

Department of Electrical Engineering

Eindhoven The Netherlands

DEVELOPMENT OF TRANSMISSION FACILITIES

FOR ELECTRONIC MEDIA IN THE NETHERLANDS

by

J.C. Arnbak

EUT Report 86-E-158

ISBN 90-6144-158-7

ISSN 0167-9708

Coden: TEUEDE

Eindhoven

February 1986 
Sponsored by the European Commission

FAST Research Programme

Project COM 2: Media Industry

Section: Transmission Channels

CIP-GEGEVENS KONINKLIJKE BIBLIOTHEEK, DEN HAAG

Arnbak, J.C.

Development of transmission facilities for electronic media in the Netherlands / by J.C. Arnbak. - Eindhoven: University of Technology. - (Eindhoven University of Technology research reports / Department of Electrical Engineering, ISSN 0167-9708; 86-E-158)

Met lit. opg., reg.

ISBN 90-6144-158-7

SISO 090.1 UDC 351:654.1(492) UGI 540

Trefw.: telecommunicatie; Nederland; overheidsbeleid. 


\section{SUMMARY}

A forecasting survey of technical developments of narrowband, wideband, satellite and integrated transmission facilities for modern media in the Netherlands is attempted. It is postulated that the pace of the future developments will continue to be determined more by political, cultural and socio-economic forces, than by the present autonomous revolution of information technology. Upgrading of the relatively widespread public communication facilities, both CATV and PT'T networks, will be an evolutionary matter in the Dutch environment.

Arnbak, J.C.

DEVELOPMENT OF TRANSMISSION FACILITIES FOR ELECTRONIC MEDIA IN THE NETHERLANDS.

Department of Electrical Engineering, Eindhoven University of Technology (The Netherlands), 1986.

EUT Report 86-E-158

\section{Address of the author:}

Prof.Dr. J.C. Arnbak, Telecommunications Division, Department of Electrical Engineering, Eindhoven University of Technology,

P.O. Box 513, 5600 MB EINDHOVEN, The Netherlands 
I INTRODUCTION: SETTING THE (DUTCH) SCENE

II CABLE NETWORKS (WIDEBAND CHANNELS) 3

2.1. Technology 3

2.2. Market developments 6

2.3. Technical regulations for broadband cable networks 9

III NATIONAL (NARROWBAND) TELECOMMUNICATIONS CHANNELS 11

3.1. Technology 11

3.2. Market developments 12

3.3. Technical regulation 17

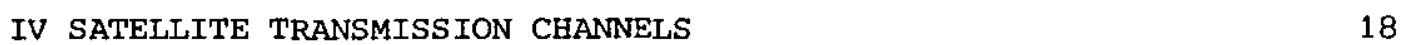

4.1. Technology 18

4.2. Market development 19

V THE FUTURE: INTEGRATION OF NETWORKS 19

5.1. Hybrid networks 19

5.2. Network integration 20

REFERENCES

APPENDICES

App. A: FAST II Research Programme (in Dutch)

App. B: General Questions - Researchers 


\section{PREFACE}

This report has been prepared as the Dutch contribution to a European survey of the expected "impact of new communication technologies on the media industry in the EC-countries", sponsored by the European Commission under its FAST research programme (described in Appendix A), as project $\mathrm{COM}-2$.

Guided by the questions listed in Appendix B, prepared by Prof. E. De Bens and Prof. M. Knoche, Vrije Universiteit Brussel, the report addresses the technical capacities and potentialities of future Dutch telecommunication networks as far as these affect the media products transmitted through these information channels.

Companion reports on the Dutch audio-visual media and the Dutch electronic text media, respectively, are prepared by other Dutch researchers (Prof. D. McQuail and Mr. G.J. Kemme, Universiteit van Amsterdam, and Prof. J.J. van Cuilenburg, Vrije Universiteit Amsterdam). For a complete forecast of the Dutch media situation, these reports should also be consulted. 
I INTRODUCTION: SETTING THE (DUTCH) SCENE.

This report, prepared for the COM-2 project of the European Community's FAST Research programme, presents a view of the Dutch developments of modern transmission facilities for the suppliers of media and their various users. By "transmission facilities" we shall understand electronic means of providing intermediary connection(s) between suppliers and users for the transport of audio or video programmes, general information and any related transactional signalling; we thus exclude pure physical transport (e.g. distribution of signs on paper or compact disc). "Modern" facilities are taken to be those which do more than support terrestrial broadcast services (over the air) or telephone and wire' services (these classical public services being available in the Netherlands for more than half a century).

It is hardly necessary to remind the reader that the Netherlands have some 14 million inhabitants and the highest density of population in the EC (344 per $\mathrm{km}^{2}$, thus exceeding even Japan). In 1980, both import and exports of goods and services for the first time exceeded 508 of the Gross Domestic Product - a factor 5 or 6 higher than for the US or Japan, and twice that of the EC average. This international orientation profoundly influences Dutch professional and personal abilities, without however dominating the political, cultural and social traditions: the democratic structure is still set up to accommodate several classical "pillars" of an outspoken religious or ideological nature [1]. Public decision-making is based on an unusual measure of egalitarian participation and is obviously no simple matter in so pluralistic circumstances. Evolving conflicts in modern society which cannot be resolved fast enough in parliament, are frequently settled in court.

Is this of importance for the present investigation of transmission facilities for modern media, which would seem mainly an assessment of technology development? It must not be forgotten that there are strong public interests involved in this course, inter alia because of

- national media policy, protective of broadcast and press traditions;

- the vast capital already invested in public communication infrastructures (CATV and PTT networks), amounting to some 15 Milliard Dutch Guilders in the Netherlands; 
- employment in the (public-utility) sectors responsible for most communications infrastructures in the Netherlands;

- industrial policy for the promising IT-sector (with the Dutch multinational Philips);

- privacy issues;

- copyright issues, both national and international in scope;

- education and science policy, e.g. in relation to teaching and research networks (the Netherlands provide the international secretariate for RARE, under the aegis of EUREKA);

- the (re-)definition of PTT monopolies, especially for new information services.

While any European government is becoming saddled with a similar set of conflicting policy problems, the Dutch have a comparatively longer exposure: Discussion about broadband CATV networks has been fierce since their inception more than 15 years ago [2], and the status and the power of the Dutch PTT have been in question almost permanently since the second world war [3]. There is ample evidence of the impact of (in-)official social processes and forces from the "pillar" system on the Dutch development of technical communication facilities. This should be borne in mind when forecasting the ability of rapid transition into the so-called "information (technology) age".

A less political, but equally complex aspect is that of user attitudes or, in more commercial terms, market forces. It is appropriate to divide end use of the various services provided by transmission facilities according to two different purposes [4], viz.

1) for entertainment; in search of personal contact, or for educational or cultural purposes (subjective use);

2) use for decision-making in a given private or professional function, whether commercial or not, including transactional use.

The former category is the extension of the general popular or social uses of classical media; it therefore has the ear of the powers that be. The latter category involves more objective types of information (data) requested by quite specific, identifiable and capable user groups; introducing new information services ("value-added services") with market success is easier in this category. 
With this brief introductory sketch of the national background for the technological development of modern transmission facilities in the Netherlands, we shall now in turn treat the status and future of wideband (CATV), narrowband (PTT), satellite and integrated networks on the Dutch scene.

\section{II: CABLE NETWORKS (WIDEBAND CHANNELS)}

\subsection{Technology}

With the exception of Belgium, the Netherlands has the highest penetration of MATV/CATV ${ }^{*}$ ) networks in the EC, namely some 708 of the 4.8 million households with TV. These broadband networks are always local, i.e., they are not permitted to cross the municipality border. Nonetheless, the large city municipalities in Holland (Amsterdam, Rotterdam and The Hague) have (some of) the largest CATV networks in Europe. Thus, the Amsterdam municipal cable provider (KTA) has around 320.000 subscribers. All Dutch networks are engineered with broadband (coaxial) cables.

The density approaching saturation (some 85\%), the main technical activities in the near future will be concentrated on replacing MATV systems (still serving more than 108 of the households) by CATV networks where economically feasible. Moreover, a number of the older CATV networks has quite limited technical capacity (6-12 TV channels) and may be refurbished where necessary and viable. Modern Dutch CATV networks are generally capable of repeating $18 \mathrm{TV}$ channels, but can be upgraded to 24-30 TV channels without new cabling, by replacing the existing repeater/amplifiers. Dutch CATV networks generally relay FM radio programmes, too.

In view of this situation, the prospect of new cabling using optical fibres appears remote. Protection of the present investments, exceeding 3 Milliard DG, and the existing service types do not warrant this new technology [5] which cannot be justified in CATV networks without new

*) MATV: Master Antenna TV (Dutch: GAI) systems have less than 100 subscribers or, if more, do not apply amplifiers after crossing public roads.

CATV: Central Antenna TV (Dutch: CAI) systems are larger, but still local. 
validated service requirements in addition to the conventional relaying of programmes (mainly public broadcasts picked off the air) now offered.

Due to parliamentary actions in 1976 [2], there is no uniformity of technical standards in Dutch CATV networks. However, most modern networks are engineered in accordance with a topology recommended by the PTT [6], the "mini-star" network. This is based on feeding stellar concentrations (of about 25 households) by a branching network. The advantages are seen in the short arms of each mini-star, allowing both UHF- and VHF-channels to reach the subscriber without further amplification; the possibility of network command and control (disconnection) at points outside the user residence; and the low cost relative to the single star with long arms to all subscribers.

The disadvantages of mini-star networks are encountered if individual subscriber services, requiring return channels, were to be provided: Then the many concentration points require a network architecture with distributed intelligence and switch points. However, the PTT will not give permission for such new (telecommunication) services, unless they can be proven to be provided cheaper or with better quality than via the PTT's own (narrowband) networks. In practice, this has confined (the possibility of) new CATV services to a few authorized pilot projects, namely, in the small town of zaltbommel and in the Southern part of the province Limburg [14].

Neither of these pilot projects was authorized for technical reasons, but to gain experience of user acceptance of new service types. The technology employed is mature, based on coaxial cables and switching techniques developed in the Netherlands during the 1970's by the University of Technology of Delft, togethex with Robert Schmitz, Ltd., (Zaltbommel), and independently by Delta Cable, Ltd (Gouda). The chief technological experience of the 1980's has been gained by an in-house (laboratory) project carried out jointly by Philips, the PTT, and the Technological Universities of Delft and Eindhoven, abbreviated DIVAC ("Digital Subscriber Connection with the local Exchange") [5]. Based on optical-fibre technology and (two!) long stellar arms, this experiment contributed to the official view that more R\&D and integration of existing and new services (wideband and narrowband) into one local network are minimal prerequisites for cost-effective use of optical 
fibres in the subscriber network. In accordance with this view, the Netherlands have supported the EC's RACE programme from the outset.

With the exception of Zaltbommel and the Limburg region, introduction of pay-TV in Dutch CATV-networks requires extra technology at subscriber premises, since the networks have not been equipped to switch programmes on or off. So far, one commercial operator (FilmNet) has initiated service in major cities, leasing a descrambler of foreign make to interested subscribers. Some eight more applicants have received authorization, without (yet?) initiating any service. It is believed that a national entertainment service may become commercially viable with half a million paying subscribers; with the abundance of national and foreign broadcast programmes already offered via CATV in the major cities, it would seen difficult to reach this level with more competing companies. This may explain the extreme reluctance of Dutch cable providers to upgrade their networks with switching facilities for individual subscriber services.

on the other hand, the many standard subscribers to Dutch CATV systems have stimulated the present use of the Fixed Satellite Service (FSS) for relaying international programmes to local cable operators. In the Netherlands, these programmes (Sky Channel, TV 5, Music Box, Europe TV) are offered to cable subscribers at no extra cost. The extra technology required must provide conversion of the scrambled, low-power satellite signals not available to the general public without CATV connection. In general, this occurs with $3-\mathrm{m}$ receive-only ground stations approved by the PTT for use in the $11 \mathrm{GHz}$ band with satellites owned by international organisations in which the Netherlands participate (EUTELSAT, INTELSAT). The first cable experiments of this kind were conducted in 1981 by unauthorized reception and relaying of the extremely high-powered emission from the GORIZONT FSS in the INTERSPUTNIK system. This carries the Soviet Moscow-1 programme (in Russian) at $3.675 \mathrm{GHz}$, with sufficient strength for reception by $1-\mathrm{m}$ dishes. Although not a Direct Broadcasting Satellite (DBS) by internationally agreed definitions of the BS service, GORIZONT acquainted the Dutch public with the notion and possibilities of DBS technology.

The widespread introduction of local wideband cable systems, during the $1970^{\prime}$ 's and $1980^{\prime}$ 's, has not reduced the (number of) traditional broadcast 
channels; in fact, Dutch CATV networks largely rely on many radio and TV programmes, both domestic and foreign, picked off the air (and, more recently, satellite). However, it may be argued that the inherent competition to the traditional Dutch broadcast operators has reduced their quality and removed their representative "pillar" identity. Fear of this has been the motivation for heavily regulating the access to Dutch CATV networks, a matter better discussed in the companion papers about the audio-visual and electronic text media. Technical regulations are discussed in Section 2.3 below.

Another fear, that of a threat from the future DBS to CATV operations, seems largely unfounded in the Netherlands. With the high CATV density in the Dutch-speaking part of Europe (including Flanders in Belgium), it would appear unlikely that special DBS programmes will be justified for this region: broadcast programmes can be offered at much lower cost both terrestrially and by low-powered FSS to cable head ends. DBS reception (without cable intermediaries) may well play a role for minority interests (foreign labour; scholars; radio amateurs) and in the event of too restrictive cable regulations. Nevertheless, for the average Dutch user, continued CATV subscription will always prove much cheaper than procuring and maintaining a small individual receiving station suited for several frequencies, polarisations and orbital locations. It should not be forgotten that many urban Dutch users live in circumstances without adequate clearance to the geostationary orbit. They must therefore invoke a collective antenna system of some kind for DBS reception; Dutch wideband operators will rather prosper than perish by this.

The real threat to present CATV operations will arise when integration with narrowband services in one subscriber network (using optical technology) becomes economically viable. This situation is dealt with in Section $v$.

\subsection{Market developments}

The Dutch tradition developed in cable provision is one of heavy involvement by municipalities or their public-utility providers (gas and water companies). More than $85 \%$ of CATV franchises has been granted to municipal authorities or to foundations with municipal control. These 
entities may leave financing, construction and operation of a CATV network to private companies (including the PTT's daughter CASEMA, the largest Dutch cable operator); nevertheless the spirit of a public utility provider prevails in Dutch CATV operations. Cable operation is a common-carrier activity.

Although future access regulations may evoke a different balance, there is little scope for a market attitude as long as cable programming is tied strongly to public broadcasts and national pay-TV companies with their own market organisation. Moreover, the cable provider holds a monopoly in a local area, and thus is not subject to any other competition than that of air broadcasts (including radio pirates) and private video recording. His best weapons against thèse are joining as many broadcasts as possible (sometimes including popular radio pirates:) with superior technical quality ${ }^{*}$, thus satisfying also the video recorder owner who wishes access to programme material for later play-back (time-shifting). Subscriber reactions confirm that technical quality and cost-effectiveness are the principal reasons for subscription: some CATV operators have been sued for breach of contract in this respect, often with success.

The modes of financing of municipal CATV networks are similar to that of other construction works commissioned by local public authorities in the Netherlands. Central government and the PTT are not directly involved in financing; the latter however provides the backbone highquality trunk connecting the different parts of a town with highreliability cabling, at a price determined by the PTT.

The tariffs differ widely between municipalities, being far more dependent on network size and technical capacity, than on actual programme content. Until an important decision by the supreme court (in 1984) to the effect that separate copyxights are due for all broadcast programme material even if directly retransmitted off-air, the tariffs were based on amortisation of the capital investment over an agreed period of time, plus the running costs. The average investment per subscriber approaching 1000 DG, this has led to monthly basic subscription xates of 10-15 DG in large CATVs, and more than twice that in

*) This may involve PTT delivery of signals, from places beyond the municipal border with better reception, to the CATV network. 
smaller networks. These 'flat' connection rates have generally been so independent of the active channel loading that the cost per cable programme may differ by more than an order of magnitude between Dutch cable networks! This suffices to show that the carrier offering by CATV networks can be characterized neither as a true public service (with fair and non-discriminatory pricing), nor as having a value determined by commercial market forces. In fact, this pricing is a consequence of the political history [2] and regulation of CATV networks in the Netherlands.

A slight element of cost proportionality with the number of programmes offered was introduced after the decision by the Supreme court referred to above, because of the extra costs passed on to the subscriber (Pay-TV channels are obviously another matter, amounting typically to 35 DG extra per month). However, the absence of switching facilities in Dutch CATV networks make programme-based tariff offerings a complicated matter. It is expected that segmented offerings of a few permanent programme packages can be made with relatively simple (static) filtering techniques in the mini-star points. However, the substantial capital costs of the network cannot suddenly be parcelled out proportionally, without resulting in major dissatisfaction of users so long accustomed to a fixed flat subscription rate.

Cross-subsidization of new local (cable) programmes by channel rentals received from pay-TV companies, or from the international providers of international satellite-carried programmes, is planned in some municipalities. However, the commercial success of the former and the willingness of the latter sources have yet to be proved; so far, no significant revenues have accrued to Dutch CATV companies from the providers of the programmes or services carried.

Summing up the financial situation and "marketing" approach of Dutch CATV network providers, their precarious position as a carrier, i.e., an intermediary between large programme providers (outside their own control) and users at large (looking for the purposes of Category 1 mentioned in section $I$, and for technical quality and cost-effective reception), has been decisive. Their position was developed in the 1970 's, before the notion or feasibility of new information services (Category 2 in Section I) was sufficiently generally appreciated to 
allow political acceptance of a more active involvement in this field [2]. Accordingly, CATV in the Netherlands has been regulated as a form of broadcast activity. Hence the A (for Antenna), and hence the restricted scope of the regulations in force.

\subsection{Technical regulations for broadband cable networks}

Franchising for collective "antenna installations" (i.e. local cable networks) was made possible by an 1969-amendment to the Telegraph and Telephone Act of 1904. This vests the authority to designate special types of cable "broadcast" networks which may be provided without a licence (but with a franchise), in the cabinet Minister of Traffic and Public Works, who is to inform the cabinet colleague responsible for broadcast matters of his decision(s). The formulation of the various conditions for obtaining a cable franchise, and the granting of franchises, is delegated to the Director General of the PTT.

The ministerial designation of the CATV/MATV network types which may be so provided was made in July 1970, and most recently amended in 1983 with the possibility to include receive-only FSS earth stations as part of such "antenna" networks. The procedure and conditions for obtaining a franchise from the DG of the PTT include:

- a (favourable) hearing of the local authorities;

- agreement with (mild) technical recommendations [6]; and adherence to the specific administrative and technical conditions in force;

- acceptance of PTT-provision of certain (trunk) facilities, against payment;

- sufficient evidence of technical and financial competence of the applicant;

- compliance with the relevant (content) regulations of the Broadcasting Act for regional programmes and for cable programming (see below);

- payment (to the PTT) of administrative costs.

The additions in brackets indicate the prevailing administrative practice in granting CATV franchises.

Once established, a local CATV network is seldom controlled in respect of meeting the technical quality prescribed in the franchise; a service 
quality deemed unacceptable by subscribers is best addressed by suing the cable provider in a civil court case. The practical exercise of its powers of control and sanctions by the Government has been very much focused on cable content; therefore the minister responsible for broadcast matters is, in general, involved in state proceedings against cable providers. However, he may attempt to invoke existing or new technical requirements (through the good offices of the Ministry of Traffic and Public Works, or the PTT), rather than getting formally engaged in the more controversial matter of direct state control of information content.

A recent example of this approach was caused by the unauthorized local broadcasting by radio and TV pirates, who are exceedingly numerous in the Netherlands, apparently for want of authorized local programming and local advertising [7]. Their popularity induced some cable providers to leave empty channels open to pirate accesses. Also, many cable providers found their relayed official programmes jammed, or even replaced, by stronger pirate transmissions directed at the community antenna, thus sparing the clandestine pirate the cost and risk of an omnidirectional (broadcast) transmitter. While the state itself has failed to control ether piracy at the source, the cable franchise system provided it with an opportunity to oblige the CATV providers to prevent relaying of pirate emissions. This has been formulated as an additional technical requirement [8]; the actual difficulties and great cost of implementing adequate antenna suppression techniques have, however, caused indefinite deferment in the application of this public order in the event of FM radio pirates. To meet its private contractual obligation to subscribers, the Amsterdam cable provider (KTA) has been ordered by court to ensure interference-free reception of promised programmes via PTT relay from regions (possibly abroad) less ridden by ether pirates.

The telecommunications relaying of programmes from beyond the municipality's border cannot be done without technical assistance from the PTT, as the franchise does not entitle the cable provider to infringe the national telecommunications monopoly. Since the resolution of a long-lasting copyright issue by the said decision of the Supreme court (ruling that programme copyrights are always due, irrespective of whether the relayed programmes are available on the air locally or not), 
an earlier reluctance of cable providers to apply for relaying has diminished: they can now just as well improve the technical quality in this way, when copyrights are payable in any event. Terrestrial relaying is offered at commercial (distance-dependent) rates by the PTT, using mainly microwave radio relays. The receiving end of a FSS satellite relay may be operated by the cable provider, under the 1983-amendment of the franchise system mentioned earlier [9].

The dual position of the PTT, as a regulating authority and a monopoly service provider of transmission facilities for CATV networks, does not please every cable provider, especially not since the PTT also engages actively in CATV operations through its private daughter company (CASEMA, Ltd.), whose chairman is the DG of PTT. The position will become much clearer when the PTT becomes a limited liability company in 1989, passing all regulatory responsabilities back to the Ministry (Section III). However, a fear by CATV providers of ultimate integration of all local services into one (optical) subscriber net, owned and controlled by PTT, Ltd., is presently becoming evident (Section V).

\section{III: NATIONAL (NARROWBAND) TELECOMMUNICATIONS CHANNELS}

\subsection{Technology}

Technology for future full digitalization of the PTT networks (telephone, telex and data) is being installed by a "top-down" approach, beginning with tmuk exchanges and trunk transmission forming a "thinned" national overlay network (IDN*). These exchanges are fully ISDN-prepared** and are being procured from the Philips and AT\&T Telecommunications joint venture, from L.M. Ericsson, and (later) from ITT. All trunk transmission facilities ordered from now on will be either optical or digital microwave relay. Analogue and coaxial trunk facilities are thus being phased out in an evolutionary programme, the speed of which depends only on the availability of extra funds (See 3.2). All technical standards are fully CCITT-compatible.

The plans for the subscriber network required to provide users with (narrowband, i.e. up to $2 \times 64+16 \mathrm{kbit} / \mathrm{s}$ ) ISDN channels, are not yet known. Its costs being dominant and highly dependent on technological

* Integrated Digital Network, ready in 1987.

** Integrated Services Digital Network 
and market developments, this local network may not be available to residential users for another 10-15 years. Moreover, the investment planning is highly dependent on the future possibility of integrating broadband transmission into the subscriber network, thus combining all residential access into one (optical) subscriber loop. It is unlikely that the Dutch PTT will commit itself in this area prior to a political decision on the recommendations of the zegveld Committee, which has been tasked with a study of this integration, due on January 1, 1987. (Section V).

However, a professional user anywhere in the Netherlands will be able to install digital facilities (with speeds up to 2 or $8 \mathrm{Mbit} / \mathrm{s}$ ) when IDN is complete in 1987-88. A special access loop will be required, with a length not to exceed some $15 \mathrm{~km}$, to the nearest IDN digital exchange. Moreover, special "agglomeration" networks in metropolitan areas are being installed in Amsterdam, The Hague and Rotterdam, providing local digital access to the many professional users in these important industrial and government centres. Transmission is based on optical cabling, coupled with IDN and a local satellite terminal for (digital) business communications. Thus, digital broadband facilities are now becoming available to business subscribers in these areas, including large suppliers of (electronic) media services. These will consequently become able to reach all CATV networks in the Netherlands (through IDN, upon completion of the latter), and any foreign business users by satellite ("Teleport"). The Dutch PTT being responsible for all agglomeration networks, these are certain to be fully standardized according to the (lowest three layers of the OSI model recommended by) CCITT.

The operational significance of being able to reach local CATV networks through a digital PTT network is dependent upon regulatory developments. Technically, it will be possible to deliver digital services to CATV networks all over the Netherlands as from 1988.

\subsection{Market developments}

The international consolidation of the concept of Integrated Services Digital Network (ISDN) and the rapid development of optical-fibre technology by philips and its competitors abroad have resulted in 
increasing appreciation of the need for extra investments in the PTT infrastructure, which might prove difficult to finance via the government budget. The diverse needs of professional telecommunication users (Category 2 in section I), and the many new opportunities offered by micro-electronics suggest a new terminal market far too complex for any one organisation, be it PTT, Philips, or IBM. Last, but not least, there have been the ongoing different liberalisation moves in the US, the UK and Japan, namely

- divestiture of telecommunications oligopolies in the US;

- privatisation of state-owned operating companies in the UK and Japan;

- structural separation of information processing and transport sectors;

- open competition in the supply of customer-premise equipment and information processing services with "added value", relative to the public service;

- a measure of competition in providing transmission channels for information transport, consistent with the national interpretation of the "public interest".

These five international trends have not always been clearly distinguished in the national Dutch debate [3]. Yet they have contributed to a better understanding of the necessity to study not only the tasks and functions of the PTT [10], but more recently also its status (as a government department) and structure (as a regulator, a monopoly provider of public utilities, and a competitor with private enterprises).

In January 1984, a Government White Paper stated: "Further reflection on the status and structure of the PTT should not concentrate solely on its present functioning - which is found to be basically sound in terms of technology and organisation - but should be addressed to future [19] developments". The Government requested Dr. Steenbergen, an economist with senior executive experience in corporate automation, to chair a committee addressing the future status and structure of the Dutch PTT. He proceeded to set up a study which broke with several traditions in Dutch political life:

1. Rather than reflecting the many "pillars" and diverse commercial interests in the Dutch society, the steenbergen Committee consisted of only three independent experts, supported by a professional secretariate. 
2. The Committee acquainted itself with the various desires of users, manufacturers, unions, industrial branches, government departments, and the PTT itself, by conducting confidential hearings. These demonstrated a far greater consensus than the official stances taken in public, or by delegates in advisory bodies.

3. The Committee examined the developments abroad of particular relevance to the Netherlands, by paying official visits to the post and telecommunication authorities and operating agencies in Belgium, West Germany, the UK, Switzerland, Denmark, Sweden and Finland, and to the EC Commission. This allowed "cream skimming" of the advantages of many different organisational forms, and insight into their undesirable constraints, as perceived by the managers on location.

4. The Committee was working together with an international team of management consultants from McKinsey \& $\mathrm{Co}$, who compared the strengths of different PTT organisations, their entrepreneurial capacities and financial ties with the state, and their ability to meet customer demands in a given regulatory environment [11].

This approach allowed the Steenbergen committee to complete its report to the Government in less than one year [12]. Its recommendations enjoyed a substantial measure of public support almost immediately after the publication on July 1, 1985. On November 22, 1985, the Council of Ministers decided to endorse these recommendations.

The key point of the Cabinet decision and the ensuing white Paper is the restructuring of the PTT from its present departmental status into a limited-liability holding company, PTT Ltd., as from January 1, 1989. Separate subsidiary companies will be dedicated to Post and Telecommunications operations. All related regulatory and franchising functions will be transferred to a new Office of Regulations and Permits (ORP), to be set up within the Ministry of Traffic and Public Works. This will take over the executive powers now delegated to the PTT, which then will become able to focus on its unambiguous rôle as an enterprise.

In the public interest, PTT Ltd. will be granted an exclusive licence by ORP to carry out the national infrastructural activities for all information transport; the present monopoly services of post and telecommunications will thus be continued by the subsidiary companies. However, the present PTT monopoly on peripheral (customer-premise) equipment 
will be completely abolished.

All shares of PTT Ltd. will be held by the State. At the press conference following the Cabinet decision on November 22, the Prime Minister, Mr. Ruud Lubbers, saw no purpose in later selling the shares on the stock market: The principal goal will be a more independent and flexible PTT enterprise, not privatisation which would only diminish the - very substantial - annual revenues enjoyed from the Dutch PTT (Fig. 1). However, in order to reverse the present declining investment trend, PTT Ltd. will be granted access to foreign capital on market conditions.

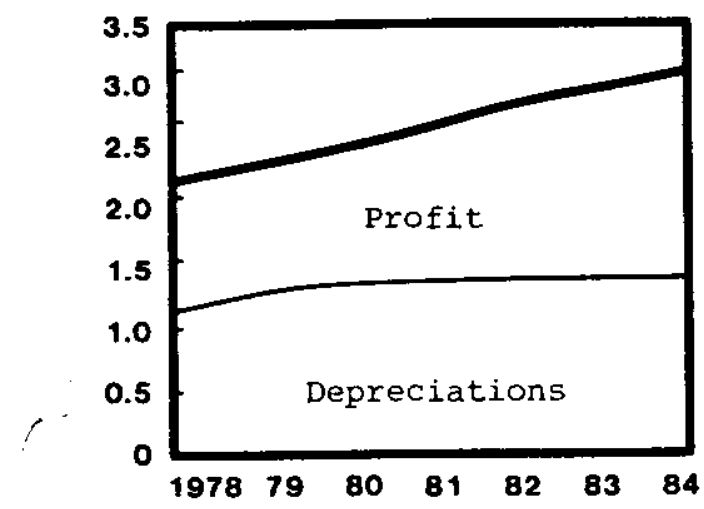

Annual PTT results

in Milliards of Dutch Guilders.

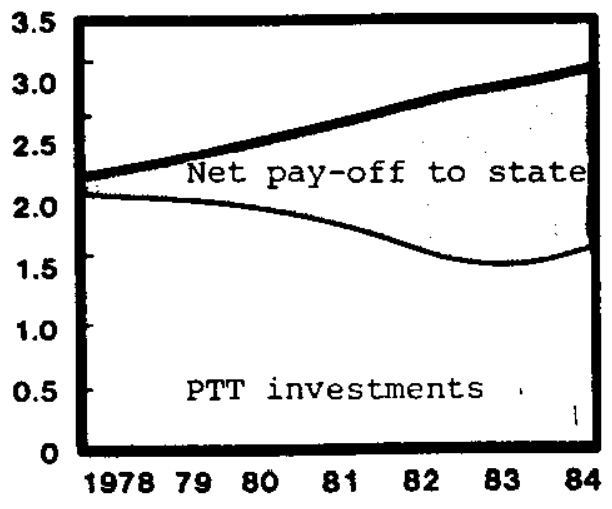

Spending of annual results, in Milliards of Dutch Guilders.

Fig. 1: Financial trends in Dutch PTT, showing the stagnation of depreciatons and investments and the growth of profit and pay-off $[12\rfloor$.

In preparing its 1985 White Paper, the Cabinet had adopted these lines of action from the Steenbergen Committee's blueprint [12], entitled "Signals for Soon. A new direction for the PTT". Only one signal has not been well received by the PTT, namely, the Committee's proposal to split telecommunications operations between two subsidiary companies. One of these should carry out the licenced monopoly functions, and the other offer the various competitive activities, such as installation of equipment on customer premises and operation of new tele-information services. The rationale for this proposed split is twofold: on the one hand, protection of the public interest (tariffs!) from the inevitable commercial risks on the future fully competive market, combined with the avoidance of unfaix competition on the other hand, from the PTT using its special 
licenced status or impenetrable public cross-subsidies for its private venture activities.

The PTT strongly objects to this proposed split: "In the light of [the] recent drastic reorganisation within the Telecommunications Division, and the complex truncating of utility and entrepreneurial functions, further [splitting up of the Telecommunications subsidiary] is now thought ... undesirable and unprofitable because of the high risk involved" [13].

Following petitions from various Dutch industrial and publishing organisations in favour of the Steenbergen advice, the Cabinet did decide for the split, but at a later date than in 1989, yet to be decided. It is believed that this concession to the PTT has secured political support for the entire plan from the major opposition party; if so, the implementation will not be dependent on the outcome of the elections in May 1986. The PTT has expressed a strong desire for a very rapid transition, to avoid protracted periods of political uncertainty and structural ambivalence.

Other significant elements of the Government plan, in agreement with the Steenbergen recommendations, are that

- government control (as a shareholder and as a regulator) must be restricted to major policy matters;

- PTT employees will cease to be civil servants in 1989. This will permit the salary adjustments necessary to recruit and keep more specialists and commercial staff, necessary for successful innovation;

- the telecommunications licence granted to PTT Ltd. will impose an obligation to provide leased lines (both narrowband and wideband) on request. Third-paxty traffic (resale) with added value will be allowed, subject to a permit from ORP;

- the Government will be advised on infrastructural policy matters by a (small) Telecommunications Council;

- PTT Ltd. is to consult a body of users and suppliers about its future plans and public services;

- all proposed measures will be carried out together, as one package deal. 
Assessing these specific Dutch developments in the light of the five international liberalisation trends outlined above, the following picture emerges :

- Unlike AT\&T, the PTT will not be subjected to the exigencies of divestiture. The Dutch economies of scale do not even amount to those of one large American state, let alone all the United States.

- Unlike British Telecom, the ownership of the PTT will not be privatized. However, PTT Lta. will enjoy a legal status separate from the government executive, with the rights and obligations of a company governed by private law.

- Stmuctural separation between those subsidiary PTT companies serving the public interest and those pursuing private interests will be achieved. In the telecommunications sector, a national monopoly will defined by an exclusive licence from government, consistent with the international developments towards ISDN and thus comprising the "bearer services" of the 3 lower layers of the Open Systems Interconnection (OSI) model. The somewhat related structural dichotomy of "basic" and "enhanced" services developed in typical us antitrust proceedings, and advocated by IBM, is not adopted.

- Open competition will be introduced for all customer-premise peripherals and for new (ISDN) "tele-information services", defined by functions in the 4 upper layers of the OSI model.

- The extent of future competition allowed in "bearer services" between the local CATV providers and the national PTT will be considered in the light of European objectives expressed in the EC's RACE programme, which explores the feasibility of one integrated and standardized (public) infrastmucture for all digital transport services, including broadband video. A separate study of this specific "media" aspect has been commissioned by the Government, for completion by January 1, 1987 (See Section V).

\subsection{Technical regulation}

A sufficiently large market for new digital consumer services in the Netherlands requires a national infrastructure. Thus, local CATV networks may play a rôle in these developments (only) if allowed supply from national or even international providers of non-broadcast information, by either terrestrial (PTT) or satellite relay. This will require 
far more uniformity of technical standards in CATV networks and user terminals, and far less rigid rules for access to these networks, than at present. Such developments must presumably await evaluation of the said pilot experiments in Zaltbommel and Limburg [14], before national priority to new digital services is likely to be given. The PTT is likely to be very reluctant to take initiatives in this field before loosing its regulatory authority in 1989, especially since this might erode the market basis for the advanced national infrastructure to be provided by the PTT sometime after 1989.

\section{IV: SATELLITE TRANSMISSION CHANNELS}

\subsection{Technology}

The principal limitation of satellite relaying for mass-media usage is that both the FSS and the DBS are mainly suited for one-way distribution of programme material, including down-loading of digital software to multiple users. Thus, the technology used will be highly dependant on the degree of uniformity and penetration of standardisation of user terminals in Europe.

The protracted difficulties of EBU member states in accepting common technical standards for the DBS (despite the early British and Scandinavian attempts towards multiplexed-analogue component (MAC) television standards and the early German digital audio proposals) have given added impetus to the use of the FSS to CATV head ends. Further advantages of the FSS are its much lower space-segment costs (at least a factor five to seven lower than for a similar DBS service); the possibility of other uses of FSS technology than the mere support of broadcasts; and a more familiar legal and regulatory context of international telecommunications, compared with the delicacy of international broadcasts from space!

Persistence on DBS will come from states wishing to promote their national industry, or to broadcast to large, otherwise inaccessible regions at home or abroad. Mutatis mutandis, such arguments might also be invoked at the European level. In that case, they must be considered in the light of any programmes for terrestrial broadband infrastructures within the EC, e.g. a Transnational Broadband Backbone (TBB) optical 
network in Europe.

\subsection{Market development}

Dutch aerospace policy strongly supports the European Space Agency (ESA) . Government funding of national satellites for FSS or DBS is unlikely. Private investments in national satellites are equally unlikely. Any national use of satellites will be in those developed or owned together with other member states, e.g. Olympus, ECS and INTELSAT.

The attitude of successive Dutch cabinets to satellite relaying of broadcast programmes (by FSS) has been protective of the domestic broadcasting system, which is partly financed by a national advertising monopoly (STER). To protect this system, FSS-relayed foreign programme material containing advertising directed at Dutch customers, or with Dutch subtitles, is not allowed retransmission by Dutch CATV networks at present. The EC Commission is highly critical of this nationalist attitude [15].

In the autumn of 1985, the court of Justice in The Hague, dealing with an complaint against this policy, has requested a preliminary ruling from the European Court of Justice, to assist delivery of a national decision about the legality of this protectionist policy under the Rome Treaty. The Dutch government defends its national policy by recourse to the constitution and various other treaties [16].

The DBS might become more attractive for Dutch CATV networks and direct reception in the Netherlands if the present restrictions of the FSS were to be endorsed in court. In most other circumstances, there appears to be little market potential for DBS in the Netherlands, for the practical reasons stated in 4.1 and the end of section 2.1 .

V: 'THE FUTURE: IN'I'EGRATION OF NETWORKS

\subsection{Hybrid networks}

The satellite developments discussed above show the significance of embedding the local CATV networks in other networks, in order to expand the present media offering. In a technical sense, this is possible 
(only) if the PTT accepts the resulting service as one which PTT is unable to offer. Priority of PTT services and of its national infrastructure is understood.

A clear example of this is the use of the FSS for relaying of broadcast programmes to CATV networks. This takes place in the $11-\mathrm{GHz}$ frequency band shared with terrestrial PTT microwave relays. The relevant franchise conditions [9] clearly stipulate that the franchise does not entitle the cable provider to satellite reception free from interference from (PTT) relays. It is not unlikely that the future heavy use of $11-\mathrm{GHz}$ digital radio relays in Europe may rule out acceptable conditions of foreign satellite reception at many places in the (flat) Netherlands, either permanently or from time to time [17].

An ingenious coupling between the Dutch telephone network and local CATV networks has been developed by the United Dutch Publishers, Itd. (VNU), under the commercial name Ditzitel [14]. The absence of return signalling from the subscribers in a Dutch CATV network - see Section 2.1 - is compensated for by employing the signalling system of their PTT telephone; this may be used for individual requests of information directed to the CATV operator's computer. In response, a CATV video channel may be used to direct (videotex) information to the subscriber concerned. This coupling is particularly inexpensive for users who already have a TV-monitor with a teletext decoder and a push-button telephone. It should be noted, however, that push-button telephones are not yet standard in the Dutch PTT system; they still cost 50 DG more than conventional (dialling) telephones.

A tactical advantage achieved by VNU with Ditzitel will be increased PTT revenues, both from the hybrid subscriber network and from leased PTT lines supplying the CATV operators' computers from the VNU central videotex library. Because of this and a potentially much shorter response time than in PT'T's own videotex service (Viditel, based on the British Prestel), VNU has seen fit to obtain permission for this national service, to be officially introduced in 1986.

\subsection{Network integration.}

As discussed in sections $2.3,3.2$ and 3.3 , the technological developments 
in digital transmission and new customer-premise equipment will, sooner or later, result in a situation in which the local CATV network and the PTT subscriber network will both be able (in a technical sense) to support similar services, both narrowband and broadband. To investigate the related implications for planning, management and regulation, the Dutch government in 1985 commissioned a study by a panel of interested parties (including the PTT, the municipalities, Philips, the commercial service providers and the cable providers), chaired by prof. Walter Zegveld and supported by outside consultants from PA Associates in the UK and Belgium.

This committee is due to report on the future of Dutch broadband cable networks before January 1, 1987. Its longer study period and its return to a more classical Dutch accommodation of various conflicting interests, compared to the Steenbergen Committee discussed in Section 3.2, suggest that it will be difficult to reach consensus about when and how to integrate the services of the present coaxial CATV cable networks into one (optical) subscriber network capable of supporting both narrowband and wideband, one-way and two-way services.

It is probable that, once again, the pace of future network developments in the Netherlands will be determined rather by political, cultural and socio-economic forces, than by the present autonomous revolution of information technology [18]. In these circumstances, upgrading of the already widespread public communication facilities of Dutch CATV and PTT networks will, most likely, be an evolutionary matter. Integration could be expedited by mounting pressures from the big manufacturing industry inside or outside the Netherlands. It might equally well be extended by accepting more liberal rules for access to and hybrid expansion of the existing CATV coaxial networks in the Netherlands, which - after all - presently form the most embracing broadband infrastructure within the European Community. 


\section{REFERENCES}

[1] Lijphart, A.

THE POLITICS OF ACCOMODATION: Pluralism and democracy in the Netherlands.

Berkeley: University of California Press, 1975.

[2] Schrijvex, F.J.

DE INVOERING VAN KABELTELEVISIE IN NEDERLAND.

's-Gravenhage: Staatsuitgeverij, 1983.

Wetenschappelijke Raad voor het Regeringsbeleid: Voorstudies

en achtergronden mediabeleid, M 17. (With an English summary). ISBN $90-12-04264-X$

[3] Arnbak, J.

REDRESSING THE EUROPEAN PTT MONOPOLIES.

InterMedia (International Institute of Communications, London), Vol. 13, No. 1 (Jan. 1986)

ISSN $0309-118 \mathrm{X}$

[4] Arnbak, J.C. en J.L. Bordewijk

BASIS VOOR EEN TELE-INFORMATIEBELEID. Eindrapport Projectgroep Beleid Informatietoepassingen.

Available from: Distributiecentrum Overheidspublikaties, Postbus 20014, 2500 EA 's-Gravenhage. ISBN 90-346-0227-3

[5] Heijden, J. van der

HET DIVAC PROJECT.

Voordracht gehouden tijdens een gemeenschappelijke vergadering van het NERG, de Sectie Telecommunicatie KIvI en de Benelux Sectie IEEE.

Tijdschrift van het Nederlands Elektronica- en Radiogenootschap, vol. 48(1983), p. 171-177.

Ekkelenkamp, H.

ASPECTEN VAN DIGITALE GLASVEZELVERBINDINGEN IN DIVAC.

Ibid., p. 179-183.

Etten, W. van

AUDIODISTRIBUTIE IN HET DIVAC-"IN HOUSE"-SYSTEEM.

Ibid., p. 185-188.

Roetering, R.L.J.

A/D-CONVERSIE VAN VIDEO-SIGNALEN EN LIJNCODERING.

Ibid., p. 189-199.

Groen, H.B.

$64 \mathrm{~kb} i t / \mathrm{s}$ COMMUNICATIE.

Ibid., p. 201-204.

Coenen, A.J.R.M. en C.M. van der Knaap

HET ONTWERPEN VAN EEN DIGITALE BREEDBANDIGE SCHAKELMATRIX.

Ibid., p. 205-210.

Diggele, J. van

TERMINALS EN SIGNALERING.

Ibid., p. 211-215. 
Stijl, M.

HET DIVAC VIDEOTHEEKSYSTEEM.

Ibid., p. 217-225.

[6] TECHNISCHE VOORSCHRIFTEN VOOR CENTRALE ANTENNE-INRICHTINGEN EN GEMEENSCHAPPELIJKE ANTENNE-INRICHTINGEN. 5 delen.

's-Gravenhage: Afdeling Draadomroepsystemen, Centrale Afdeling Transmissie, Centrale Directie PTT, 1978.

[7] ETHERPIRATEN IN NEDERLAND. Studie verricht door Intomart B.V. 's-Gravenhage: Staatsuitgeverij, 1982.

Wetenschappelijke Raad voor het Regeringsbeleid: Voorstudies en achtergronden mediabeleid, M 6.

ISBN 90-12-04001-9

[8] Ministerial Decree dated 25 May 1982.

Ministeries van Cultuur, Recreatie en Maatschappelijk Werk (CRM) en van Verkeer en Waterstaat (V\&W) .

[9] Ministerial Decree dated 6 Sept. 1983.

Ministerie van Verkeer en Waterstaat (V\&W).

[10] TAAK EN FUNCTIE VAN DE PTT GEZIEN IN HET LICHT VAN DE INFORMATIE- EN TELECOMMUNICATIETECHNOLOGIE. Rapport van de Commissie Swarttouw. 1982.

Available from: Centrale Directie PTT, Postbus 30000, $2500 \mathrm{GA}$ 's-Gravenhage

[11] Appendices to the Steenbergen Report [12] (partly in Dutch), July 1985.

Available from: McKinsey \& Co., Amstel 344, 1017 AS Amsterdam

[12] SIGNALEN VOOR STRAKS: Een nieuwe richting voor de PTT. Rapport van de Commissie Steenbergen. 2 vol. July 1985. Available from: Distributiecentrum Overheidspublikaties, Postbus 20014, 2500 EA 's-Gravenhage.

[13] PTT IN MOTION. Sept. 1985. English transl. of the PTT position on [12]. Available from: Centrale Directie PTT, Postbus 30000, $2500 \mathrm{GA}$ 's-Gravenhage

[14] Berg, A.J. van den en F.K. Kappetijn, F.J. Olderaan DE KABELEXPERIMENTEN IN ZUID-LIMBURG, AMSTERDAM EN ZALTBOMMEL. i\&i, Kwartaalreeks over Informatie en Informatiebeleid (VUGA, 's-Gravenhage), No. 12 (Dec. 1985), p. 7-18. ISSN $0167-9740$

[15] Reply by European Commission to Parliamentary Question No. 978/84, dated 1 Febr. 1985.

[16] ADVIES COMMISSIE BOUKEMA OVER HET DOORGIFTEVERBOD VAN BEPAALDE OP NEDERLAND GERICHTE BUITENLANDSE OMROEPPROGRAMMA'S TEGEN HET LICHT VAN GRONDWETTELIJKE BEPALINGEN EN INTERNATIONALE VERDRAGEN.

Rijswijk: Ministerie van Cultuur, Recreatie en Maatschappelijk Werk, Oct. 1982 . 
[17] Arnbak, J.C.

KABEL EN SATELLIET IN DE NABIJE TOEKOMST.

i\&i, Kwartaalreeks over Informatie en Informatiebeleid

(VUGA, 's-Gravenhage), No. 4 (Dec. 1985), p. 26-32.

ISSN 0167-9740

[18] Arnbak, J.C.

NIEUWE INFORMATIEDIENSTEN EN TELEMATICA.

In: De Informatiemaatschappij: De gevolgen van de microelektronische revolutie. Onder red. van $M$. de Kok.

Maastricht/Brussel: Natuur en Techniek, 1983. P. 135-159. ISBN $90-70157-35-7$

[19] REGERINGSSTANDPUNT OVER DE TAAK EN FUNCTIE VAN DE PTT MET BETREKKING TOT INFORMATIE- EN TELECOMMUNICATIETECHNOLOGIE. Tweede Kamer, vergaderjaar 1983-1984, 17370, nr. 3. 


\title{
INVLOED VAN DE NIEUWE COMMUNICATIE- TECHNOLOGIEEN OP DE MEDIA-INDUSTRIE IN EG-LANDEN (COM 2)
}

\begin{abstract}
Situering van het onderzoeksproject COM 2 in het onderzoeksprogramma FAST II
In 1978 werd door de Commissie van de E.G. een grootscheeps onderzoeksprogramma op touw gezet onder de algemene benaming van FAST (Forecasting and Assessment in Science and Technology). Dit project beoogt de multi-dimensionele analyse van de jongste wetenschappelijke en technologische ontwikkelingen. $\mathrm{Na}$ een eerste faze (FAST I, 1978 - 1982), werd voor een tweede periode (FAST II, 1984 - 1987) als eén van de centrale onderzoeksthema's het fenomeen "Communicatie" uitgekozen.

De onderzoeksactiviteiten werden opgedeeld in negen projecten. Het project "media-industrie", genoemd COM 2, werd aan Prof. E. De Bens en Prof. M. Knoche van de afdeling Communicatiewetenschap van de Vrije Universiteit Brussel toegewezen.

Het project loopt over 16 maanden en het eindrapport zal in mei 1986 neergelegd worden. Ondertussen zal reeds in januari 1986 een internationale workshop georganiseerd worden.
\end{abstract}

\section{Onderzoeksobjectieven}

Dit project zal de gevolgen op lange termijn van de nieuwe communicatietechnologieën bestuderen. De verschillende innovaties, die het resultaat zijn van een aantal determinerende factoren, zullen de structuren van de media-industrie, media-instellingen, de aard van de mediaproducten alsook de verwachtingen en behoeften van de media-consumenten grondig wijzigen.

Uitgaande van een analyse van het verzamelde datamateriaal en de empirische bevindingen, zullen scenario's ontwikkeld worden waarin potentiële communicatiemodellen voor 1995 worden uitgetekend. Deze scenario's zullen uiteindelijk aanbevelingen geven voor een toekomstig mediabeleid en een industriële strategie voor de E.G.

\section{Onderzoeksthema's en schema}

Het onderzoek zal zich concentreren op audio-visuele media, electronische tekstmedia en de transmissiekanalen, zowel met het oog op privé als professioneel gebruik.

Het onderzoek verloopt in vier fasen:

\section{Fase 1}

In deze fase van het onderzoek wordt het huidig profiel van de media-industrie, -instellingen en -consumptie in de verschillende E.G. Ianden geanalyseerd en vergeleken, zodat gelijkenissen, verschillen en configuraties tussen de E.G.-mediasystemen en consumptiepatronen zullen naar voor treden.

\section{Fase II}

Deze fase is dynamisch en toekomstgericht. Hier zullen de belangen-perspektieven en de vooropgestelde strategieën van de vier belangrijkste communicatie'"actoren" worden geïdentificeerd en dit voor een periode van ongeveer twintig jaar. Deze actoren zijn: de media-industrie, de overheid, media-instellingen (privé en overheid) en de consumenten.

\section{Fase III}

In deze fase zullen de opties van de actoren waarvan sprake in fase II, worden geconfronteerd met een aantal maatschappelijke factoren, zoals ekonomische, politieke, sociale en kulturele variabelen. Hieruit zullen een aantal toekomstscenario's worden gedistilleerd inzake mediatrends. Het gaat hier om prognoses ivm nieuwe communicatiefuncties als gevolg van de introductie van nieuwe technologieën. 


\section{Fase IV}

Uiteindelijk zullen deze verschillende scenario's worden geëvalueerd met het oog op het formuleren van aanbevelingen voor de Europese media-industrie en het mediabeleid op lange termijn. Leidraden zullen ondermeer worden geformuleerd inzake samenwerking voor de media-industrie en media-instellingen binnen de EG, de rol van de EG in de internationale nieuwsflow, compatibiliteit van technische standaards en transmissiekanalen, uniformisering van de wetgeving en het nieuwe evenwicht dat moet gezocht worden tussen de openbare en privé sectoren in de verschillende E.G.-landen.

\section{Onderzoeksmethoden}

a. Systematische analyse en evaluatie van recente literatuur, van voorhanden zijnde data en pilootprojecten.

b. Analyse van de rapporten van het E.G.-netwerk van academische researchers, gekwalificeerd in de toekomstige ontwikkeling van nieuwe communicatietechnologieën.

c. Delphi-interviews van media-experten, werkzaam in de media-industrie, media-instellingen, reciame en beleidsvorming in de verschillende E.G. Ianden

d. Opiniepeiling in België naar gebruik, behoeften en verlangens van potentiële consumenten. 


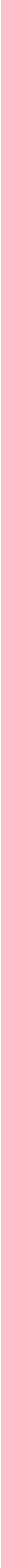




\section{APPENDIX B}

GENERAL QUESTIONS - RESEARCHERS :

\section{IRANSMISSION :}

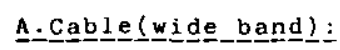

1) Technology:

- How widespread is the cable at present and what sort of density is en visaged for the future?

- What are the prospects for the use of optical-fibre cable? If there is no optical-fibre option, or if the optical-fibre project should fail to materialize, what are the alternatives?

- How is the network to be structured ? (branching,stellar,etc.)

- In the technological field, what experience has been gained from the different pilot projects? What conclusions have been drawn from this

- To what extent will the cable influence traditional transmission chan nels? Is cable transmission likely to be retained when we know that for instance, satellite broadcasting will shortly be picked up by dish antennas and viewdata by digital telephone link-up?

2) Market devel opment:

a) Agents/Groups

- Can you provide information on the relative position taken by the government on the one hand and private companies on the other with respect. to this area of activity? Do you expect any changes in the rutu re with respect to the present position?

- Do you think that the cable companies will he prompted by the prospec of new uses for the cable to get involved in marketing and market research? As a result, what are they likely to want to emphasize in this respect and which companies are in the forefront of this develop ment?

b) Costing/Finance

-What sort of costing is foreseen for installation, maintenance and ru ning? I.e. inttial investment and running costs?

- How are these costs to be covered? Will government or private capita or both be approached for financing? 


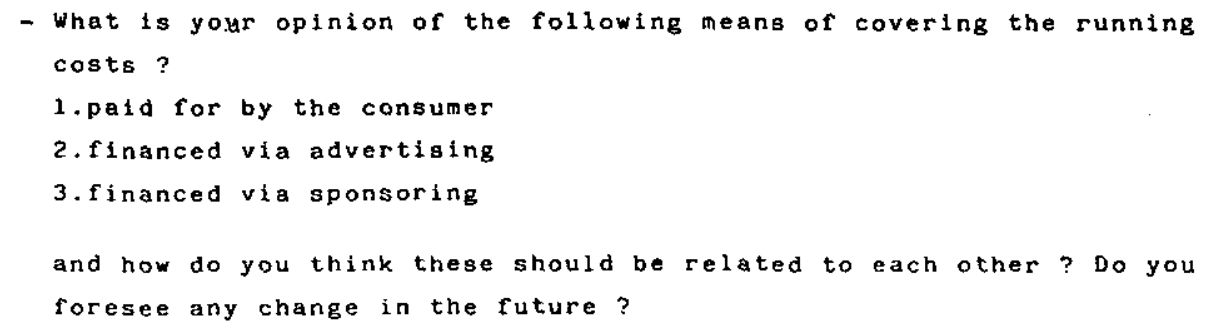

3) Legal-political framework:

- Can you sum up present legislation with respect to the cable and do you see any crucial points with respect to further development?

- Is there in your country a body legally competent to regulate. control and/or pronounce sanctions?

- Can you sum up any regulations pertaining to copyright/advertising laws in connection with the cable and do you foresee any changes in these?

\section{B.Telephone\{narrow band):}

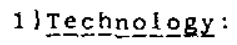

- When and where (i.e. in which areas) is the telephone network likely to be digitalized and with what capacities and possibilities?

- What are the chances of compatible standards and norms for the different services?

- Do you see any possibilities of combining narrow and wide band (telephone and cable) ?

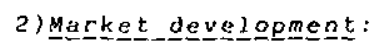

a) Agents/Groups

- With respect to the provision, installation and running costs of the equipment, do you think that these will be borne solely by the state, solely by private capital or by a combination of the two? 
- Can you give us an idea of the costs of digitalizing the network ?

- Do you think the consumption market (e.g. the public at large as well as the professional public) will be big enough to be commer cially sound?

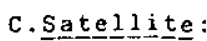

\section{1) Technology :}

- Do you think that the usual communications satellites have sufficient capabilities, so that DBS becomes unnecessary?

- If so, how come DBS-plans stranded, and what are your prognoses for the future in this respect?

- If DBS arrives anyway, can we expect in that case a system unifor mization on the European level?

- Will satellite TV be received via dish antennas or via the control stations of the cable companies?

\section{2 ) Market development:}

a) Agents/froups

- Does the share of your country for usual commuications satellites or DBS come solely from the government, or is private capital als involved (if so,which groups?) ? In this respect, how do you expect this situation to evolve?

- Will your country conduct a protectionist policy, and do you thir that (eventually) maintaining an own system threatens the commerci al viability of an (eventual) European DBS-project ?

- Do you forecast an increase or decrease in the use of Intelsat satellites for data-, telephone- and image transmission; do you think your country will make more use of their own infrastructures

b) Costing/Finance

- Can you give us a cost efficiency analysis for satellite equipment both for the usual communications satellites and for DBS? who, i the final analysis, will be expected to cover these costs?

- Do you consider DBS to be financially feasible? What is your prog nosis? 
(138) Nicola, V.F.

A SINGLE SERVER QUEUE WITH MIXED TYPES OF INTERRUPTIONS: Application to the modelling of checkpointing and recovery in a transactional system.

EUT Report 83-E-138. 1983. ISBN 90-6144-138-2

(139) Arts, J.G.A, and W.F.H. Merck

TWO-DIMENSIONAL MHD BOUNDARY LAYERS IN ARGON-CESIUM PLASMAS.

EUT Report 83-E-139. 1983. ISBN 90-6144-139-0

(140) Willems, F.M.J.

COMPUTATION OF THE WYNER-ZIV RATE-DISTORTION FUNCTION.

EUT Report 83-E-140. 1983. ISBN 90-6144-140-4

(141) Heuvel, W.M.C. van den and J.E. Daalder, M.J.M. Boone, L.A.H. Wilmes INTERRUPTION OF A DRY-TYPE TRANSFORMER IN NO-LOAD BY A VACUUM CIRCUIT-BREAKER. EUT Report 83-E-141, 1983. ISBN 90-6144-141-2

(142) Fronczak, J. DATA COMMUNICATIONS IN THE MOBILE RADIO CHANNEL. EUT Report 83-E-142. 1983. ISBN 90-6144-142-0

(143) Stevens, M.P.J. en M.P.M. van Loon EEN MULTIFUNCTIONELE I/O-BOUWSTEEN. EUT Report 84-E-143. 1984. ISBN 90-6144-143-9

(144) Dijk, J. and A.P. Verlijsdonk, J.C. Arnbak DIGITAL TRANSMISSION EXPERIMENTS WITH THE ORBITAL TEST SATELLITE. EUT Report 84-E-144. 1984. ISBN 90-6144-144-7

(145) Weert, M.J.M. van

MINIMALISATIE VAN PROGRAMMABLE LOGIC ARRAYS. EUT Report 84-E-145, 1984. ISBN 90-6144-145-5

(146) Jochems, J.C. en P.M.C.M. van den Eijnden TOESTAND-TOEWIJZING IN SEQUENTIELE CIRCUITS. EUT Report 85-E-146, 1985. ISBN 90-6144-146-3

(147) Rozendaal, L.T. en M.P.J. Stevens, P.M.C.M. van den Eijnden DE REALISATIE VAN EEN MULTIFUNCTIONELE I/O-CONTROLLER MET BEHULP VAN EEN GATE-ARRAY. EUT Report 85-E-147, 1985. ISBN 90-6144-147-1

(148) Eijnden, P.M.C.M. van den A COURSE ON FIELD PROGRAMMABLE LOGIC. EUT Report 85-E-148. 1985. ISBN 90-6144-148-X

(149) Beeckman, P.A. MILILIMETER-WAVE ANTENNA MEASUREMENTS WITH THE HP8510 NETWORK ANALYZER. EUT Report 85-E-149. 1985. ISBN 90-6144-149-8

(150) Meer, A.C.P. van EXAMENRESULTATEN IN CONTEXT MBA. EUT Report 85-E-150. 1985. ISBN 90-6144-150-1

(151) Ramakxishnan, S. and W.M.C. van den heuvel SHORT-CIRCUIT CURRENT INTERRUPTION IN A LOW-VOLTAGE FUSE WITH ABLATING WALLS. EUT Report 85-E-151. 1985. ISBN 90-6144-151-X

(152) Stefanov, B. and L. Zarkova, A, Veefkind DEVIATION FROM LOCAL THERMODYNAMIC EOUILIBRIUM IN A CESIUM-SEEDED ARGON PLASMA. EUT Report 85-E-152. 1985. ISBN 90-6144-152-8

(153) Hof, P.M.J. Van den and P.H.M. Janssen SOME ASYMPTOTIC PROPERTIES OF MULTIVARIABLE MODELS IDENTIFIED BY EOUATION ERROR TECHNIOUES. EUT Report 85-E-153. 1985. ISBN 90-6144-153-6

(154) Geerlings, J.H.T.

LIMIT CYCLES IN DIGITAL FILTERS: A bibliography 1975-1984. EUT Report 85-E-154. 1985. ISBN 90-6144-154-4

(155) Groot, J.F.G. de THE INFLUENCE OF A HIGH-INDEX MICRO-LENS IN A LASER-TAPER COUPLING. EUT Report 85-E-155. 1985. ISBN 90-6144-155-2

(156) Amelsfort, A.M.J. van and Th. Scharten A THEORETICAL STUOY OF THE ELECTROMAGNETIC FIELD IN A LIMB, EXCITED BY ARTIFICIAL SOURCES EUT Report 86-E-156. 1986. ISBN 90-6144-156-0

(157) Lodder, A. and M.T. van Stiphout, J.T.J. van Eijndhoven ESCHER: Eindhoven ScHematic EditoR reference manual. EUT Report 86-E-157. 1986. ISBN 90-6144-157-9

(158) Arnbak, J.C DEVELOPMENT OF TRANSMISSION FACILITIES FOR ELECTRONIC MEDIA IN THE NETHERLANDS. EUT Report 86-E-158, 1986. ISBN $90-6144-158-7$ 